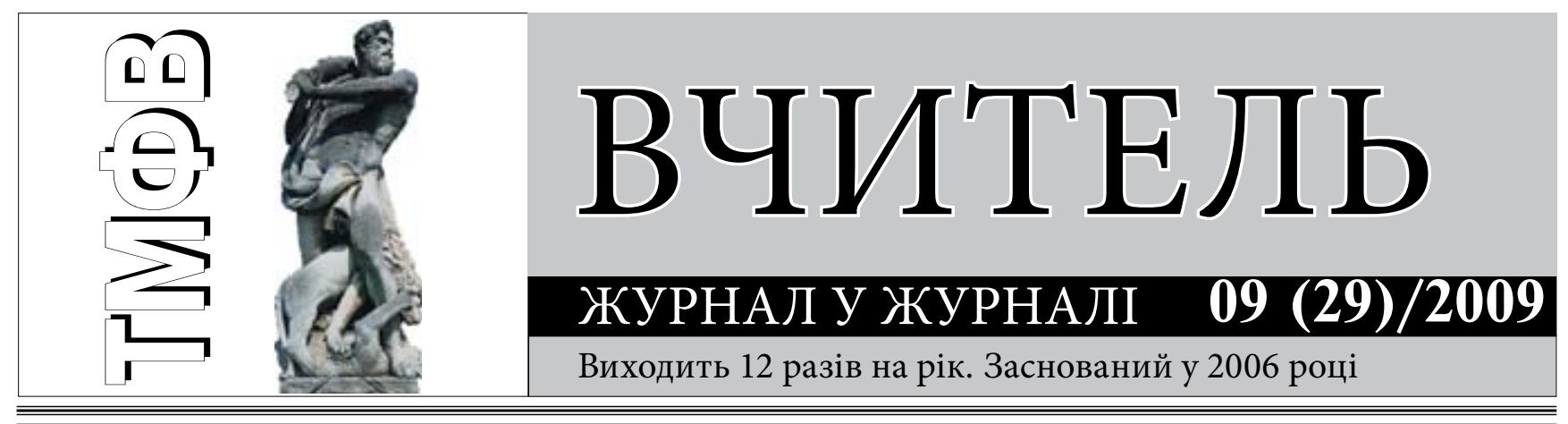

\title{
ТЕХНОЛОГІЯ НАВЧАННЯ ГІМНАСТИЧНИМ ВПРАВАМ
}

\author{
Худолій О.M. \\ Харківський національний педагогічний університет імені Г.С. Сковороди
}

Анотація. У статті розглядаються загальні підходи до методів навчання, які використовуються у фізичному вихо-
ванні. Дана характеристика методам навчання, технологізації процесу навчання гімнастичним вправам.
Ключові слова: метод, метод навчання, метод алгоритмічних розпоряджень.

\section{Вправи у висах}

Для учнів молодших класів пропонується виконання вправ у змішаних висах. Цим вправам навчають цілісним методом.

\section{Вправи у змішаних висах}

Виконуючи вправи у змішаних висах, учні оволодівають різноманітними прийомами перелізання через перешкоди, а також підготовляються до виконання вправ у висах, лазанні та ін.

Вис стоячи - похиле положення тіла стоячи 3 хватом за снаряд, тулуб і ноги випрямлені, голова прямо (рис. 8).

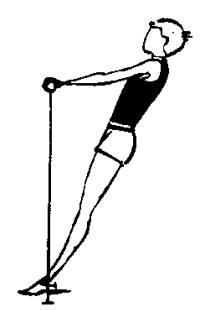

Рис. 8

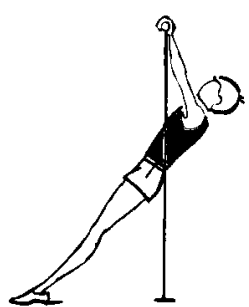

Рис. 9
Вис лежачи відрізняється від вису стоячи - кутом нахилу тіла щодо підлоги. Кут повинен бути не більш $45^{\circ}$. Треба навчити учнів розрізняти кут нахилу тіла, виконуючи вис лежачи із нахилом тіла на $45^{\circ}, 35^{\circ}, 25^{\circ}$. Контролюючи і терміново інформуючи учнів про помилки, що допускаються, навчити ї безпомилково і швидко приймати положення вису лежачи $з$ різними кутами нахилу тіла (рис. 9).

(С Худолій О.М., №8, №9
Вис лежачи ззаду відрізняється від вису лежачи тим, що учень знаходиться в положенні спиною до снаряду. Зручніше всього його виконувати із вису стоячи ззаду або із стійки спиною до снаряду нахилом тулуба вперед і захватом снаряду руками ззаду (рис. 10).

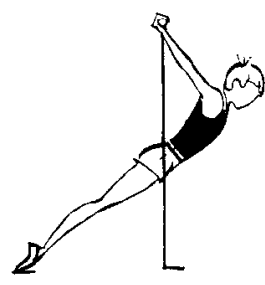

Рис. 10

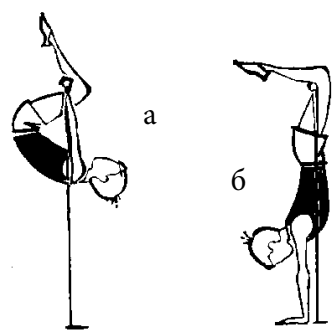

Рис. 11
Вис на двох - положення на снаряді, в якому тіло утримується в висі на підколінках (або носках, п’ятах) і руках. Вис на двох виконується: на перекладині, одній чи двох жердинах брусів, на драбині, колоді, похилому чи горизонтальному канаті, на брусах різної висоти.

Вис на двох з опорою руками об підлогу виконується із вису двома відпусканням рук (рис. 11, a) і повільним випрямленням тіла головою униз i опорою руками об підлогу (рис. 11, б). Вправа закінчується поверненням у в. п. або зіскоком в упор присівши.

\section{Програми навчання}

Для учнів середніх і старших класів пропонується виконувати прості вправи у висах, яким навчають, головним чином цілісним методом. Найбільш 
складною вправою у висах є підйом переворотом в упор.

\section{1. Підйом переворотом в упор}

3 вису стоячи (на перекладені, жердині тощо) поштовхом однієї і махом другої підйом переворотом. Для виконання цього підйому необхідно в момент поштовху і маху ногами утриматися у висі на зігнутих руках i, використовуючи мах ногою, підняти ноги і тулуб якомога вище і ближче до снаряду. У момент, коли ноги будуть вище точок хвату, розгинаючи руки, наблизити тіло до снаряду і упертися об нього животом, а потім, підтягуючись і розгинаючись, перейти в упор (рис. 12).

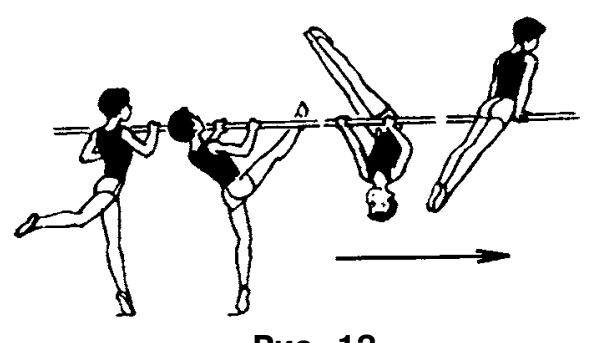

Рис. 12

Навчальні завдання

1. Згинання та розгинання рук у висі (3-4 рази).

2. Вис на зігнутих руках (5 c).

3. 3 вихідного положення лежачи на животі на низькій перекладині перехід в упор.

4. 3 упору повільно опуститися уперед у вис лежачи (під час опускання ноги не повинні падати).

5. Із вису стоячи на зігнутих руках швидко виконати вис прогнувшись, піднімаючи ноги уперед-уверх.

6. Те саме, але утримуючи випрямлене положення тіла біля перекладини.

7. Із вису стоячи поштовхом однієї і махом другої підйом переворотом.

\section{Упори}

\section{Програми навчання}

$$
1-4 \text { класи }
$$

У молодших класах виконуються прості вправи в упорах, які спрямовані на розвиток рухових здібностей. Навчання здійснюється методом цілісного розучування.

\section{5-8 класи}

У середніх класах вправи в упорах ускладнюються. 3 нових елементів вивчаються: $з$ упору махом назад зіскок, з упору на передпліччях підйом махом назад (бруси).

\section{3 упору махом назад зіскок}

3 упору на паралельних брусах махом уперед, спочатку незначно згинаючись, енергійно випрямити тіло уперед. Після того як тіло перетне вертикаль, виконати форсований мах назад. Коли ноги будуть вище жердин, перемістити тіло в бік, продовжуючи мах назад. У крайній точці маху швидко переставити ліву руку на праву жердину попереду правої руки і відштовхнутися правою рукою. Тіло учня повинно бути випрямленим, голова піднята.

\section{Навчальні завдання}

Перша і друга серії навчальних завдань:

1. Упор і розмахування в упорі на брусах.

2. 3 упору на колоді, коні, на жердині, на кінцях брусів махом назад зіскок. Третя серія навчальних завдань:

1. 3 упору лежачи, тіло випрямлене, швидко прогнутися i, випрямляючись, підняти спину і відштовхнутися носками від підлоги, утримуючись на руках.

2. 3 упору лежачи на коні те саме, що перша вправа, але зіскочити убік.

3. В упорі махом назад перейти в упор на одну жердину і закінчити зіскок у прогнутому положенні.

Четверта серія навчальних завдань:

1. Розмахування в упорі на брусах по заданій амплітуді. Виконати мах назад на 85-90 від вертикалі (горизонтально).

2. Те саме, але виконати мах на $130-140^{\circ}$. П’ята серія навчальних завдань:

1. Розмахування і зіскок махом назад на низьких і середніх брусах.

2. Зіскок виконати після трьох, двох і одного махів.

3. 3 сіду ноги нарізно перемах у середину і махом назад зіскок.

\section{3 упору на передпліччях підйом махом назад}

У кінці маху уперед, випрямивши тіло, почати енергійний мах назад. Раніше, чим тіло підійде до вертикалі, зігнутися так, щоб ноги трішки відстали від тулуба. Після вертикалі підсилити мах назад енергійним рухом ніг, а коли ноги будуть вище рівня жердин, зробити енергійний ривок тулубом, натискуючи руками на жердини, подати плечі уперед-уверх i, випрямляючи руки, перейти в упор.

\section{Навчальні завдання}

Перша і друга серії навчальних завдань:

1. В упорі на брусах згинання і розгинання рук максимально швидко (5 раз за 4 с). 
2. В упорі лежачи на передпліччях на гімнастичній лаві, ноги на 5-6 рейці гімнастичної стінки, тіло прогнуто, швидко випрямляючись і піднімаючи спину перейти в упор лежачи.

3. Лежачи на животі на коні, тримаючись руками за рейку гімнастичної стінки, прогинаючись, швидко підняти ноги назад. Третя серія навчальних завдань:

1. В упорі на брусах розмахування з великою амплітудою з хльостоподібним рухом ногами назад.

2. Те саме в упорі на передпліччях. Четверта серія навчальних завдань:

1. Розмахування в упорі на передпліччях по заданій амплітуді. Виконати мах назад на $120-$ $130^{\circ}$.

2. Те саме в упорі.

П’ята серія навчальних завдань:

1. Підйом махом назад з упору на передпліччях на кінцях жердин з допомогою.

2. Те саме на середині жердин.

3. Те саме самостійно.

$$
\text { 9-11 клас }
$$

У старших класах в упорах вправи ускладнюються. 3 нових елементів вивчаються: 3 упору на руках підйом махом уперед, підйом розгином, стійка на плечах силою.

\section{3 упору на руках підйом махом уперед}

У крайній точці маху назад, коли тулуб і ноги підіймуться вище жердин потрібно округлити спину. По ходу маху уперед, не доходячи до вертикалі, хльостоподібним махом прогнутися і пружно провисаючи в плечових суглобах, енергійно направити ноги уперед-уверх, згинаючись у кульшових суглобах (до $\left.135^{\circ}\right)$. Трохи раніше, чим ноги досягнуть рівня жердин, різко розігнутися, пригальмувати рух ніг, виконати енергійний ривок грудьми і відштовхнутися плечима від жердин. Натискуючи руками на жердини, перейти в упор, продовжуючи мах уперед (рис. 13).

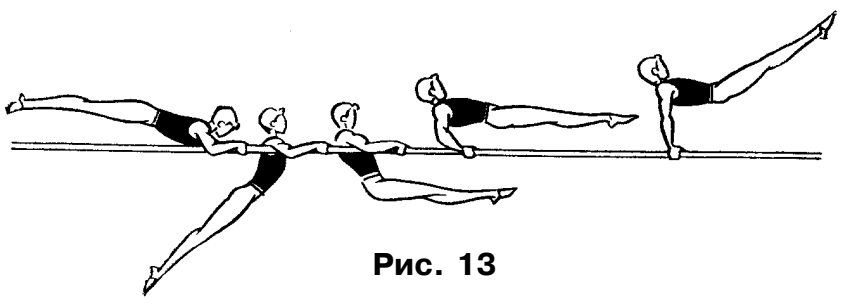

Навчальні завдання

Перша серія навчальних завдань:

1. Згинання і розгинання рук в упорі максимально швидко (5 раз за $3-4$ c).
2. 3 упору на руках ривком підйом в упор. Друга серія навчальних завдань:

1. Фіксувати упор лежачи ноги нарізно на брусах.

2. Упор на руках з додатковим вантажем з провисанням в плечах. Третя серія навчальних завдань:

1. Розмахування в упорі на руках по максимальній амплітуді.

2. Розмахування в упорі на руках з акцентованою увагою на хльост ногами уперед-уверх і активне відштовхування плечима від жердин.

Четверта серія навчальних завдань:

1. Розмахування в упорі на руках по заданій амплітуді.

2. Розмахування в упорі на руках з мінімальним збільшенням маху уперед.

3. Розмахування в упорі на руках з підльотом і мінімальним збільшенням маху уперед.

П’ята серія навчальних завдань

1. 3 упору махом назад зігнути руки, махом уперед випрямити (рис. 14).

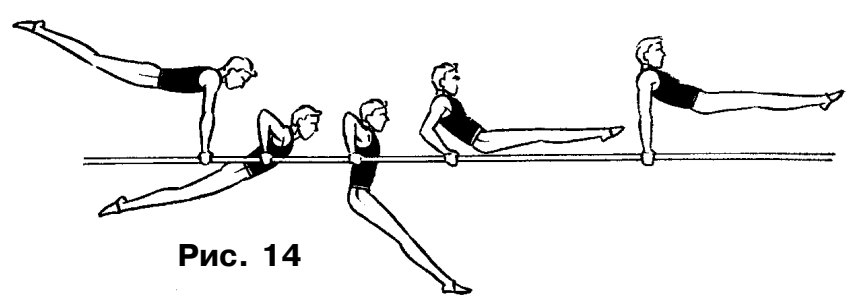

2. 3 упору на передпліччях підйом махом уперед.

3. На похилих брусах підйом махом уперед в сід ноги нарізно.

4. Підйом махом уперед з допомогою.

5. Підйом махом уперед самостійно.

6. Підйом махом уперед - зіскок махом назад.

\section{2. Із вису зігнувшись підйом розгином}

3 розбігу прийняти положення вису зігнувшись, коли тіло пройде вертикаль (від точок хвату), почати коротке енергійне розгинання. Одночасно слід активно натиснути руками на жердини у напрямку назад. Виходячи в упор незначно зігнутися, а потім розігнутися, подаючи таз і ноги уперед (рис. 15).

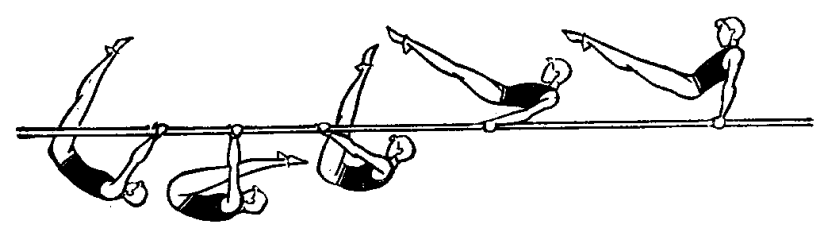




\section{Навчальні завдання}

Перша серія навчальних завдань:

1. Лежачи на спині, піднімання прямих ніг.

2. Те саме утримуючи ногами набивний м'яч.

3. У висі піднімання прямих ніг до торкання перекладини.

Друга серія навчальних завдань:

1. 3 розбігу вис зігнувшись.

Третя серія навчальних завдань:

1. Розмахування у висі зігнувшись. Четверта серія навчальних завдань:

1. Сидячи високий кут. Розгинання з переходом у положення лежачи, руки униз. Визначити кут і час, витрачений на розгинання.

2. Розмахування у висі зігнувшись з допомогою i махом назад розгинання тіла. Визначити кут розгинання.

П’ята серія навчальних завдань:

1. 3 розбігу підйом розгином у сід ноги нарізно.

2. Те саме, але в упор з допомогою.

3. 3 розбігу підйом розгином в упор самостійно.

\section{3. Стійка на плечах силою}

Стійка на плечах - випрямлене положення тіла униз головою. Гімнаст упирається на розведені убоки, зігнуті в ліктьових суглобах руки. Кисті рук обхоплюють жердини. Голова незначно нахилина назад. Стійка виконується силою з сіду (кута). Згинаючи руки і піднімаючи таз якомога вище, силою опуститись в упор на розведені убоки зігнуті в ліктьових суглобах руки з наступним розгинанням у кульшових суглобах (рис. 16.16).

Рис. 16.16

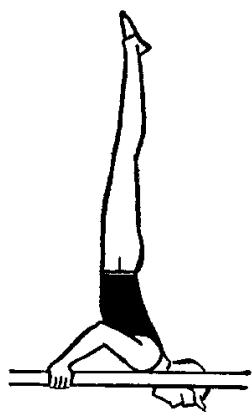

Навчальні завдання

Перша і друга серія навчальних завдань:

1. 3 упору стоячи зігнувшись на гімнастичній стінці силою вис прогнувшись 3 прямими ногами (рис. 16.5).

2. Стійка силою на голові самостійно. Третя серія навчальних завдань:

1. 3 сіду ноги нарізно перекид уперед у сід ноги нарізно повільно. Звернути увагу на опору плечима об жердини.

2. Те саме, але затриматись в упорі на плечах.
3. На стоялках махом однією стійка на плечах. П’ята серія навчальних завдань:

1. 3 сіду ноги нарізно стійка силою на плечах.

2. 3 упору кутом стійка силою на плечах.

\section{Опорні стрибки}

\section{Характеристика опорних стрибків}

Гімнастичні стрибки всебічно впливають на організм людини. Вони доступні для учнів різного віку, статі і фізичної підготовленості. 3 їх допомогою розвивають силу м'язів, швидкість, спритність і точність рухів.

Опорні стрибки - історично сформований вид фізичних вправ, що укладається в подоланні з розбігу спеціалізованої перешкоди (гімнастичного снаряду) заздалегідь заданим способом з використанням проміжної опори руками. Виконуються вони через снаряд (козел, кінь, плінт), поставлений у ширину чи довжину.

\section{Програми навчання}

Опорні стрибки вивчаються в середніх і старших класах. Головними є стрибки ноги нарізно і зігнувши ноги.

Спочатку навчання опорним стрибкам рекомендується навчити стійкому приземленню, потім - розбігу, стрибку з однієї ноги на дві і відштовхуванню ногами від мостика, далі - польоту і відштовхуванню руками. Тільки після оволодіння цими рухами можливо навчати окремим опорним стрибкам. Переліченним складовим слід навчати в $1-5$ класах.

Стрибкові вправи на першому етапі підготовки вивчаються для зміцнення м'язів ніг, розвитку стрибучості, формування уміння оцінювати рухи у просторі та за ступенем м'язових зусиль, а також для оволодіння тривким та м'яким приземленням. Ці завдання вирішуються за допомогою вправ, що рекомендуються нижче.

\section{1. Стрибки зі скакалкою:}

a) через довгу скакалку, що гойдається;

б) через довгу скакалку, що обертається;

в) на двох ногах з обертанням скакалки уперед;

г) через скакалку, що обертається, уперед зі зміною ніг - 1-й стрибок на правій, 2-й — на лівій;

д) через скакалку, що обертається, назад на обох ногах.

2. Стрибки у довжину з місия:

a) на дальність (якомога далі);

б) через 3-4 набивних м'яча підряд;

в) 5-6 стрибків по розміткам у темпі;

г) в довжину на задану відстань по орієнтирам. Орієнтиром може бути рейка, сторони якої пофарбовані в різні кольори. 


\section{3. Стрибки у висоту:}

a) з місця на горку з 5-8 матів, на плінт (1-2-3 ланки);

б) з місця через вірьовочку, рейку, натягнуту гумку;

в) з розбігу через вірьовочку, рейку.

4. Стрибки з висоти:

a) 35-8 матів або з лави;

б) $з$ плінта (2-3 ланки);

в) $з$ низької колоди або з козла;

г) $з$ підвісної площадки.

Основне призначення цих стрибків - навчити тривкому і м'якому приземленню.

\section{1. Навчання приземленню}

Перша серія навчальних завдань:

1. Вправи для зміцнення гомілкового суглоба: стоячи біля гімнастичної стінки обличчям до неї і упираючись руками на рівні грудей, підійматися на носки і опускатися на всю стопу.

2. Стрибки з опорою об стінку прямими руками i приземлення в напівприсід.

3. Вправи для зміцнення м'язів ніг.

4. Вправи для зміцнення м'язів спини. Друга серія навчальних завдань:

1. Прийняти вірне положення приземлення і фіксувати його 5 с. Півприсід на всій стопі, п'ятки разом, носки і коліна нарізно, спина пряма, руки уперед-назовні, голова прямо.

2. Стрибок уверх на місці в напівприсід на носки 3 переходом на всю стопу в позу приземлення.

Третя серія навчальних завдань:

1. 3 основної стійки, із закритими очима, швидко прийняти положення пози приземлення.

2. Стрибок у глибину з висоти $30-40 \mathrm{~cm}-$ положення пози приземлення.

3. Те саме, із закритими очима.

4. Приземлення в ціль.

Четверта серія навчальних завдань:

1. Перекид уперед і стрибок уверх прогнувшись.

2. Те саме, після $2-3$ перекидів.

\section{2. Розбіг}

Перша і друга серія навчальних завдань:

1. Махи ногами уперед, убоки, назад, упираючись об рейку гімнастичної стінки.

2. У випаді уперед правою (лівою) ногою стрибки зі зміною ніг, руки вільно рухаються.

3. Стоячи біля гімнастичної стінки, права нога на носку на рейці на рівні тазу, підскоки зі зміною положення ніг.

Третя серія навчальних завдань:

1. Виконання імітаційних рухів руками на місці.

2. Ходьба на носках з високим підніманням стегна.

3. Бігові рухи ногами лежачи на спині і в стійці на лопатках в середньому і швидкому темпі серіями по $10-30 \mathrm{c}$.
4. Біг на місці, високо піднімаючи стегно, спираючись руками об гімнастичну стінку.

5. Те саме, але без опори.

6. Спеціальні бігові вправи.

7. Біг з закиданням гомілки назад і дотиканням п'ятками сідниць, 3 незначним пересуванням уперед.

8. Рівномірний біг (без прискорення).

Четверта серія навчальних завдань:

1. Біг з прискоренням.

2. Біг по розміткам по прямій.

3. Біг по прямій лінії, ставлячи стопи на лінію паралельно.

4. Біг з заданою частотою кроків.

5. Біг через предмети, змінюючи відстань і швидкість бігу (рис. 17).

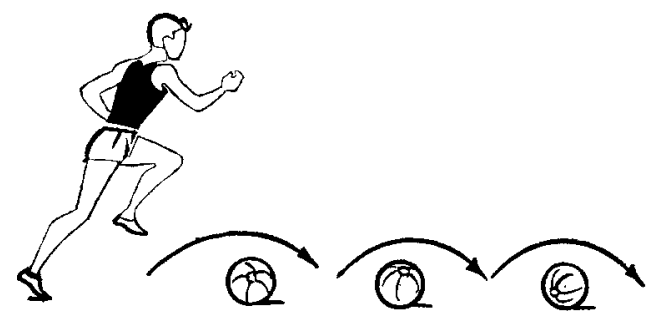

Pис. 17

\section{3. Наскок на мостик і відштовхування ногами}

Перша і друга серія навчальних завдань:

1. Ходьба перекатом з п'ятки, високо піднімаючись на носки.

2. Пружиста ходьба на носках без вантажу і з вантажем.

3. Кидок набивного м'яча двома руками знизу уверх-уперед, піднімаючись на носки в момент кидка.

4. Піднімання на носки (носок) прямих ніг, стоячи на рейці гімнастичної стінки.

5. Стрибок уверх з присіду в присід.

6. Стрибки на підвищення (5-6 матів). Третя серія навчальних завдань:

1. Стоячи на місці, імітація змаху руками, підіймаючись на носки прямих ніг у момент змаху.

2. Зі стійки на колінах змахом рук уперед встати в основну стійку.

3. Стрибки на місці поштовхом двома ногами і змахом руками.

4. Стоячи ноги нарізно поперек над лавою, стрибки на лаву з прямими ногами і махом рук.

5. $32-3$ кроків стрибок з гімнастичної лави в глибину і стрибок з махом рук уперед-уверх.

6. Те саме, виконати на підлозі. Четверта серія навчальних завдань:

1. П’ять стрибків на двох по розміткам у зручному темпі. Розмітки через 1 м. 
2. Те саме, але виконати стрибки на 1 с швидше.

3. Те саме, але виконати стрибки на 1 с повільніше.

4. Максимально високий стрибок.

5. Стрибок на половину максимальної висоти. П’ята серія навчальних завдань:

1. $32-3$ кроків розбігу махом однією і відштовхуванням другою стрибок на підвищення на дві ноги і стрибок уверх.

2. Стрибок-перекид з місця на горку матів.

3. 3 5-6 кроків розбігу відштовхування з двох ніг і стрибок на канат.

4. 3 2-3 кроків розбігу перекид уперед на горку матів.

\section{4. Відштовхування руками}

Периа і друга серія навчальних завдань:

1. Швидке згинання і розгинання рук в упорі лежачи, ноги на 3-4 рейці гімнастичної стінки.

2. Кидки набивного м'яча двома руками від грудей.

3. Стоячи на відстані 1 м від стіни, впасти прямим тілом на стіну з опорою на руки, швидко відштовхнутися і повернутися ув. п.

4. В упорі на брусах відштовхування прямими руками.

Третя серія навчальних завдань:

1. В упорі лежачи відштовхування двома руками 3 проміжними оплесками.

2. 3 упору лежачи на підлозі, перед руками гімнастична палка, відштовхуванням руками перейти в упор лежачи через палку і повернутися у в. п.

3. В упорі лежачи на підлозі одночасним відштовхуванням руками перейти в упор лежачи на 2-3-х матах.

4. 3 упору лежачи, руки на гімнастичній лаві, одночасно відштовхуючись руками і ногами, стрибок через лаву в присід на мат (рис. 18).

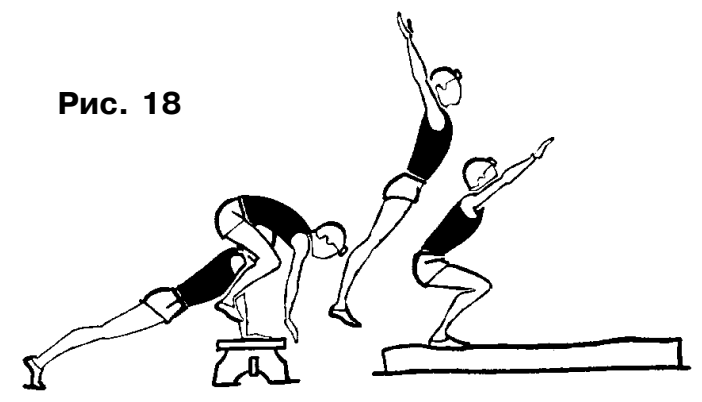

5. Стрибок ноги нарізно

Стрибок ноги нарізно - виконується 3 попереднім махом назад. Під час настрибування на мостик учень нахиляється уперед так, щоб центр тяжіння тіла знаходився ззаду площі опори. Прямі i напружені ноги торкаються мостика носками. У цей момент руки унизу або трішки попереду вер- тикалі. Учень, різко розгинає ноги в кульшових, колінних і гомілкових суглобах, відштовхується від мостика, підсилюючи відштовхування енергійним змахом руками і одночасним ривком плечима уперед-уверх.

У момент взльоту тіло незначно зігнуто в кульшових суглобах, спина округлена. Проходячи горизонтальне положення над снарядом, гімнаст прогинається і продовжує рух уверх. У момент опори руками об снаряд попередній мах ногами назад повинен бути закінченим. Гімнаст ставить руки на снаряд значно упереді тулуба під кутом більше $130^{\circ}$ щодо нього. Кисті рук для відштовхування ставляться паралельно. Відштовхування виконується на зустріч руху тіла. Ноги розводяться убоки тільки після відштовхування руками і одночасно тіло незначно згинається в кульшових суглобах. Після чого виконується розгинання тіла за рахунок піднімання плечового поясу уверх (рис. 19). Приземлення виконується на носки напружених, незначно зігнутих ніг з швидким переходом на всю стопу.

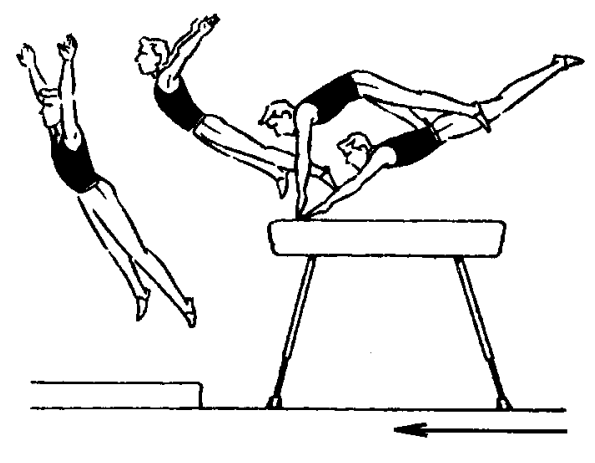

Рис. 19

Навчальні завдання

Перша і друга серія навчальних завдань:

1. 3 упору присівши стрибок уверх ноги нарізно в позу приземлення.

2. 3 упору лежачи поштовхом ніг перейти в упор стоячи ноги нарізно і швидко випрямитися. Третя серія навчальних завдань:

1. 3 2-3 кроків розбігу вскок в упор присівши і зіскок ноги нарізно.

2. $32-3$ кроків розбігу стрибок в упор стоячи зігнувшись ноги нарізно на коні з ручками і зіскок прогнувшись.

3. 3 присіду на коні стрибок ноги нарізно через коня або козла, який стоїть упереді (рис. 20).

4. Стрибок ноги нарізно через коня з ручками в ширину з місця.

Четверта та п'ята серія навчальних завдань:

1. Стрибок ноги нарізно через козла в довжину $(100-115 \mathrm{~cm})$.

2. Те саме мостик на відстані 1 м від снаряду.

3. Те саме через коня в ширину. 


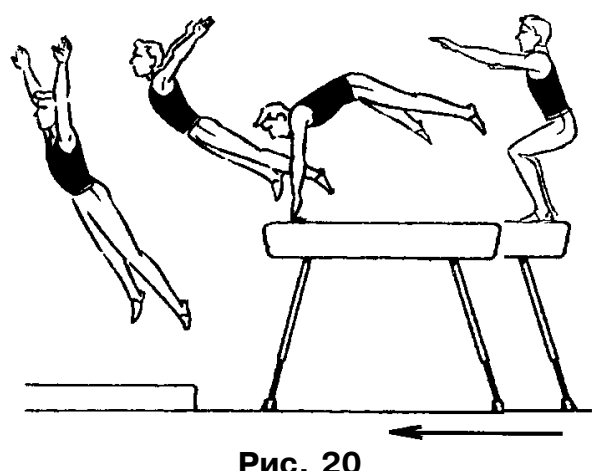

6. Стрибок зігнувши ноги

До моменту опори руками об снаряд стрибок зігнувши ноги виконується так само, як стрибок ноги нарізно. У момент опори руками тіло повинно бути прямим або незначно прогнутим. Замах виконується під кутом $30^{\circ}$ щодо горизонталі. 3 постановкою рук виконується згинання в кульшових і колінних суглобах, коліна підтягуються до грудей. Після закінчення відштовхування руками тіло розгинається за рахунок піднімання плечей і рук уверх і розгинання ніг. Випрямлене положення тіла в польоті фіксується (рис. 21).

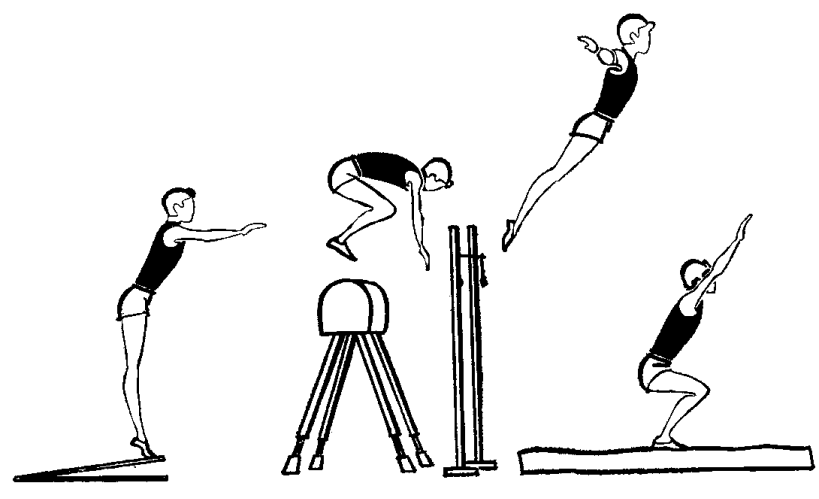

Рис. 21

Навчальні завдання

Перша і друга серія навчальних завдань:

1. 3 упору лежачи поштовхом ніг упор присівши.

2. 3 упору лежачи одночасним поштовхом рук i ногами присід, руки уперед.

3. В упорі присів стрибки з опорою руками. Третя серія навчальних завдань:

1. 3 розбігу 3 м вскок в упор присівши на козла і в темпі зіскок зігнувши ноги.

2. 3 упору присівши, руки на лаві, стрибок зігнувши ноги через гімнастичну лаву.

Четверта, n'ята та шоста серії навчальних завдань:

1. 3 5-7 кроків розбігу стрибок зігнувши ноги через козла в ширину.
2. Те саме, але стрибнути якомога далі від снаряду.

3. Те саме, але з повного розбігу.

4. Те саме, але мостик на відстані 1 м.

Технологія навчального процесу з гімнастики полягає в послідовному проходженні програмного матеріалу. Порушення технології навчального процесу веде до непослідовності у вивченні гімнастичних вправ, що подовжує час навчання. Однак програма обмежується лише переліком рухових завдань, не визначаючи порядок і тривалість вивчення різноманітних вправ.

Існує безліч варіантів вивчення одного і того самого навчального матеріалу з гімнастики. У зв'язку 3 цим завжди стоїть проблема вибору з цієї безлічі оптимального варіанта. Завдання значно ускладнюється трудомісткістю гімнастики, великою кількістю вправ, обмеженістю часу на їх засвоєння, недостатнім рівнем фізичної і технічної підготовленості учнів. Подолати об’єктивні труднощі за допомогою традиційного планування, основаного на практичному досвіді викладача, не завжди вдається. Реальну допомогу може надати графічний опис навчального процесу, що дасть можливість застосування математичних методів (моделей) для його планування.

Одним 3 таких методів $є$ система сітьового планування і управління (СПУ), що дозволяє представити навчальний матеріал 3 гімнастики у вигляді графіка 3 наступним нескладним математичним розрахунком.

Суттю сітьового моделювання є зображення комплексу запланованих робіт у вигляді графічної схеми, яка складається із заданих точок, з'єднаних лініями. Основні логічні елементи сітьового графіка - це роботи та подіi. Під дійсною роботою в гімнастиці слід розуміти будь-яку рухову дію, що вимагає витрат часу і ресурсів. До поняття «робота» відноситься і чекання - пасивний процес, що не вимагає витрат праці, фізичних зусиль, але займає час. Окрім робіт дійсних, що вимагають витрат часу і сил, існують біктивні роботи (залежності). Фіктивна робота - це логічний зв'язок між елементами, що не вимагає витрат часу і фізичної праці, але яка вказує, що можливість початку однієї роботи безпосередньо залежить від результатів іншої. Подія - підсумок зробленої роботи, проміжний або остаточний результат одного або декількох рухових завдань, що дозволить розпочати виконання наступних елементів сітьового графіка. Дійсні роботи та чекання на сітьовому графіку зображають суцільними стрілками; фіктивні - пунктирними; події - кружками, прямокутниками, квадратами або іншими геометричними фігурами з порядковими номерами. Будь-яка послідовність робіт сітьо- 
вого графіка, в якому кінцева подія однієї роботи співпадає з початковою подією наступної за нею, називається шляхом. Повний шлях з'єднує вихідну подію із завершальною. Найбільш тривалий з усіх повних шляхів даної сіті називається критичним (позначається жирними стрілками), (В.В. Трупан, 1980).

На рис. 22 наведений масштабний сітьовий графік навчання гімнастичним вправам учнів 9-х класів. Графік побудований на основі першої і другої принципових установок і дасть більш ясне уявлення про порядок навчання гімнастичним вправам шкільної програми.

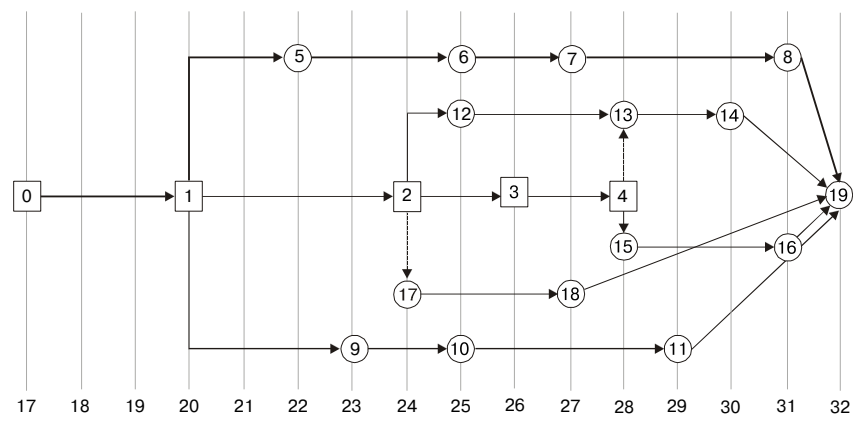

Рис. 22. Масштабний сітьовий графік навчання гімнастичним вправам учнів 9-х класів (див. табл. 1)

Ключовим моментом у побудові сітьового графіка $€$ визначення найбільш складної вправи, ланки, навколо якої зв'язуються всі вправи. Такою вправою для школярів 9-х класів може бути підйом махом вперед в упор на паралельних брусах. Цей рух складний за координацією і вимагає прояву максимальних зусиль за короткий час.

Відповідно до другої установки рухова підготовленість повинна передувати навчанню рухам, тому першою виконується робота, яка спрямована на розвиток сили розгиначів передпліччя. Присвоїмо цій роботі шифр 0-1 і занесемо в таблицю вихідної інформації (див. табл. 2.1) такі дані:

\begin{tabular}{|l|l|l|}
\hline $0-1$ & $\begin{array}{l}\text { Розвиток сили м'язів плечового поясу. } \\
\text { Комбінований метод, ІІ варіант. }\end{array}$ & уроки \\
\hline
\end{tabular}

На масштабному сітьовому графіку відкладемо пряму і позначимо подію прямокутником 1 :

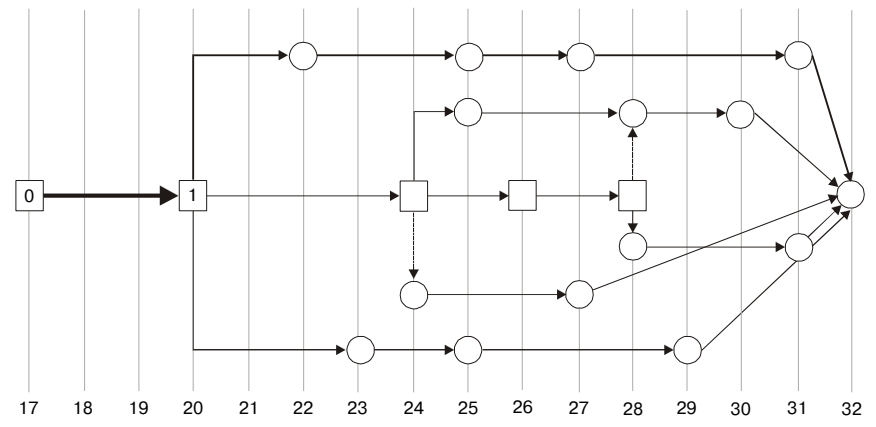

Робота 0-1 погоджується з найбільш складним рухом і направлена в нашому випадку на розвиток сили розгинача передпліччя. Засоби підбираються так, щоб вони мали структурну схожість з рухами, що вивчаються, і наближалися до них за характером м'язових зусиль. Для підвищення сили на $30-40 \%$ (подія 1) використовується комбінований метод розвитку сили, другий варіант. Силова робота організується на чотирьох послідовних станціях: I станція - метод динамічних зусиль, II станція - метод максимальних зусиль, III станція - метод ізометричних зусиль, IV станція - метод повторних зусиль.

Спеціально проведені дослідження показали ефективність такого підходу. Так, після двох тижнів занять у школярів 9-х класів збільшилася сила розгиначів передпліччя на $30-50 \%$ (О.М. Худолій, О.В. Іващенко, 1996; О.М. Худолій, А.В. Забора, 2000). Робота 0-1 продовжується 4 заняття. Заняття повністю спрямовані на розвиток сили.

Наступні роботи спрямовані на розвиток сили м'язів «спини», «рук і тулуба». Присвоїмо цій роботі шифр 1-2, в таблицю вихідної інформації впишемо:

\begin{tabular}{|l|l|r|}
\hline $1-2$ & $\begin{array}{l}\text { Розвиток сили м'язів «спини», «рук і ту- } \\
\text { луба». } \\
\text { Комбінований метод, I варіант. }\end{array}$ & 4 уроки \\
\hline
\end{tabular}

На масштабному сітьовому графіку з точки 1 відкладемо пряму і позначимо подію 2 :

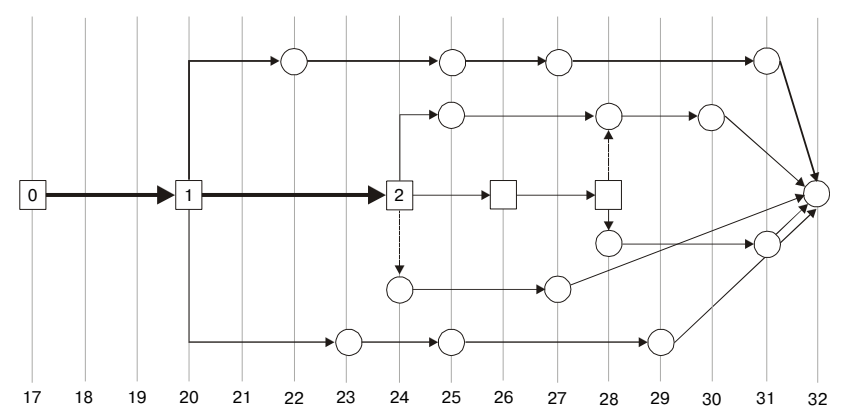

Робота $1-2 €$ базовою для навчання стійці силою на голові і руках, підйому переворотом в упор. Засоби підбираються з урахуванням особливостей навчання вищезгаданим вправам. Силова робота організується на двох станціях. Тривалість роботи на кожній станції 4-6 хв. Перша станція - вправи для розвитку м'язів спини. Учні виконують перше завдання з максимальною швидкістю, друге завдання - 3 максимальними зусиллями, третє - 3 ізометричними зусиллями, четверте - 3 повторними зусиллями. Вправи першої станції поєднуються 3 навчанням стійці силою на голові і руках. Друга станція - вправи для рук і тулуба. Всі вправи направлені на створення умов для навчання підйому переворотом силою. Підсумком роботи $1-2 \epsilon$ достатній рівень силової підготовленості для виконання названих вправ (24 заняття). 
Таблиця 1

Таблиця вихідної інформації

\begin{tabular}{|c|c|c|c|}
\hline Шифр & Робота & $\begin{array}{l}\text { Попередня } \\
\text { робота }\end{array}$ & $\begin{array}{l}\text { Кількість } \\
\text { уроків }\end{array}$ \\
\hline \multirow[t]{2}{*}{1} & 2 & 3 & 4 \\
\hline & Розвиток сили групи м'язів & & \\
\hline $0-1$ & Розвиток сили м’язів плечового поясу. Комбінований метод, II варіант & & $4(17,18,19,20)$ \\
\hline $1-2$ & Розвиток сили м’язів «спини», «рук і тулуба». Комбінований метод, I варіант & $0-1$ & $4(21,22,23,24)$ \\
\hline $2-3$ & $\begin{array}{l}\text { Розвиток сили м’язів «рук, спини і ніг», «рук і тулуба». Комбінований метод, I } \\
\text { варіант }\end{array}$ & $0-1,1-2$ & $2(25,26)$ \\
\hline \multirow[t]{2}{*}{$3-4$} & Розвиток сили м’язів «рук, спини і ніг». Комбінований метод, І варіант & $\begin{array}{l}0-1,1-2, \\
2-3\end{array}$ & $2(27,28)$ \\
\hline & Роботи спрямовані на навчання підйому махом вперед & & \\
\hline $1-5$ & $\begin{array}{l}\text { Навчання вихідним і кінцевим положенням; рухам без яких неможливо вико- } \\
\text { нання вправи }\end{array}$ & $0-1$ & $2(21,22)$ \\
\hline $5-6$ & Навчання умінням управляти рухами & $0-1,1-5$ & $4(22,23,24,25)$ \\
\hline $6-7$ & Навчання підвідним вправам & $\begin{array}{l}0-1,1-5 \\
5-6\end{array}$ & $2(26,27)$ \\
\hline $7-8$ & Навчання вправі в цілому, у сполученні & $\begin{array}{l}0-1,1-5 \\
5-6,6-7\end{array}$ & $4(28,29,30,31)$ \\
\hline \multirow[t]{2}{*}{$8-19$} & Виконання елемента в комбінації & $\begin{array}{l}0-1,1-5 \\
5-6,6-7\end{array}$ & $2(31,32)$ \\
\hline & Довгий перекид вперед з трьох кроків & & \\
\hline $1-9$ & Навчання умінню виконувати перекид вперед з різною швидкістю & $0-1$ & $3(21,22,23)$ \\
\hline $9-10$ & Підвідні вправи & $1-9$ & $3(23,24,25)$ \\
\hline $10-11$ & Вправа в цілому & $9-10$ & $5(25,26,27,28,29)$ \\
\hline \multirow[t]{2}{*}{$11-19$} & Виконання елемента в комбінації & $\begin{array}{l}0-1,1-9, \\
9-10\end{array}$ & $4(29,30,31,32)$ \\
\hline & Стійка силою на голові і руках & & \\
\hline $2-12$ & Навчання вихідним і кінцевим положенням (2 серія навчальних завдань) & $1-2$ & $2(24,25)$ \\
\hline $12-13$ & Навчання підвідним вправам (5 серія навчальних завдань) & $1-2,2-12$ & $3(26,27,28)$ \\
\hline 1 & 2 & 3 & 4 \\
\hline $4-13$ & $\begin{array}{l}\text { Фіктивна робота, яка вказує на залежність ефективності виконання стійки си- } \\
\text { лою від силової підготовленості м'язів спини і рук }\end{array}$ & $\begin{array}{l}1-2,2-3 \\
3-4\end{array}$ & \\
\hline $13-14$ & Виконання вправи в цілому & $\begin{array}{l}1-2,2-12, \\
12-13,14-13\end{array}$ & $3(28,29,30)$ \\
\hline \multirow[t]{2}{*}{$14-19$} & Виконання вправи в комбінації & $\begin{array}{l}1-2,2-12 \\
2-13,13-14\end{array}$ & $3(30,31,32)$ \\
\hline & Підйом переворотом силою в упор на перекладені & & \\
\hline $2-17$ & $\begin{array}{l}\text { Фіктивна робота, яка вказує, що початок роботи залежить від результатів ро- } \\
\text { боти }\end{array}$ & $1-2$ & $1-2$ \\
\hline $17-18$ & Виконання вправи в цілому & $1-2,2-17$ & $(25,26,27)$ \\
\hline \multirow[t]{2}{*}{$18-19$} & Виконання вправи в комбінації & $\begin{array}{l}1-2,2-17 \\
17-18\end{array}$ & $5(28,29,30,31,32)$ \\
\hline & Стрибок зігнувши ноги через козла в довжину, $h=115 \mathrm{cM}$ & & \\
\hline $4-15$ & $\begin{array}{l}\text { Фіктивна робота, яка вказує на залежність навчання від швидкісно-силової під- } \\
\text { готовки учнів }\end{array}$ & $\begin{array}{l}1-2,2-3 \\
3-4\end{array}$ & \\
\hline $15-16$ & Виконання опорного стрибка в цілому & $4-15$ & $4(28,29,30,31)$ \\
\hline $16-19$ & Виконання стрибка в умовах наближених до змагань & $4-15,16-19$ & $2(31,32)$ \\
\hline
\end{tabular}


Паралельно з роботою 1-2 продовжуємо навчання підйому махом вперед. У таблицю вихідної інформації впишемо шифр роботи $1-5$, iї назву, кількість уроків:

\begin{tabular}{|c|l|r|}
\hline $1-5$ & $\begin{array}{l}\text { Навчання вихідним і кінцевим положен- } \\
\text { ням; рухи без яких неможливо виконання } \\
\text { вправ. }\end{array}$ & \\
\hline
\end{tabular}

На масштабному сітьовому графіку відкладемо відрізок 1-5:

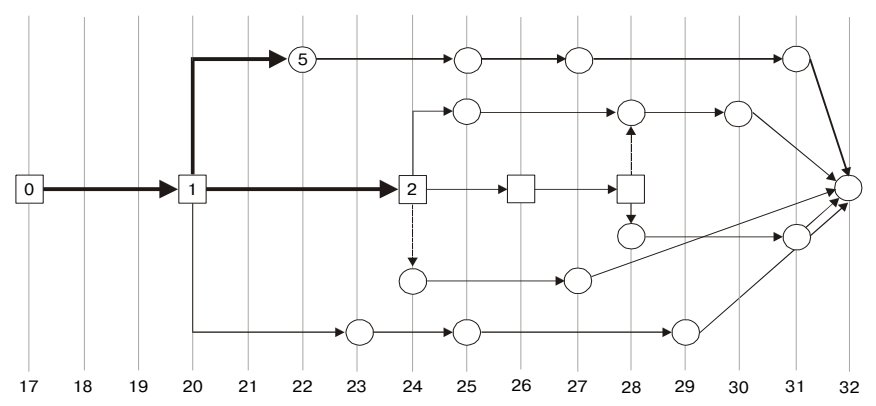

Робота 1-5 пов'язана з II та III серією навчальних завдань навчання підйому махом вперед. Тривалість роботи 2 заняття.

3 точки 1 починається робота, спрямована на навчання умінню виконувати перекиди вперед 3 різною швидкістю. Позначимо цю роботу як $1-9$ i занесемо в таблицю наступну інформацію:

\begin{tabular}{|l|l|r|}
\hline $1-9$ & $\begin{array}{l}\text { Навчання умінню виконувати перекиди } \\
\text { вперед } 3 \text { різною швидкістю. }\end{array}$ & 2 уроки \\
\hline
\end{tabular}

1-9 На масштабному сітьовому графіку відкладемо відрізок, який відповідає роботі 1-9:

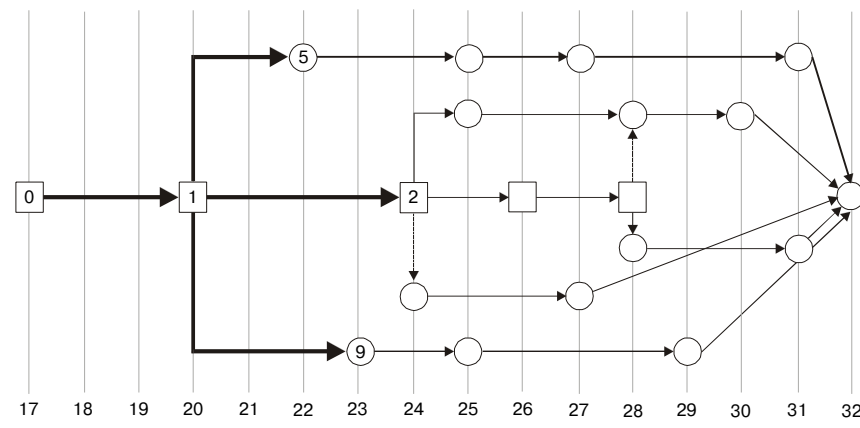

Отже роботи $1-2,1-5,1-9$ виконуються паралельно. Так як вони належать до різних структурних груп, то негативного перенесення навику не повинно спостерігатися.

Після досягнення події 2 переходимо до робіт 2-12 і 2-17. Аналогічно вищенаведеному в таблицю вихідної інформації вносимо шифр цих робіт i назву, а також відкладаємо відрізки на графіку (табл. 2.1, рис. 2.1). Робота 2-12 пов'язана з II серією навчальних завдань навчання стійці силою на голові, а робота $2-17-$ фіктивна робота, яка вказує, що можливість початку роботи безпосередньо залежить від результатів роботи $1-2$.
Після досягнення події 2 продовжуємо роботу 3 розвитку сили (робота 2-3). Силова підготовка організується на двох станціях. Перша станція - вправи для м'язів рук, спини і ніг, що направлені на створення готовності до виконання стрибка зігнувши ноги. Друга станція - вправи для м'язів рук і тулуба, що створюють умови для відмінного виконання підйому переворотом силою.

Робота 3-4 продовжує вирішувати завдання силової підготовленості, пов'язані з ефективним виконанням стрибка зігнувши ноги і підйому переворотом силою. Роботи 17-18 та 18-19 спрямовані на оволодіння підйомом силою в упор на перекладині.

Роботи 5-6, 6-7, 7-8, 8-19 спрямовані на оволодіння підйомом махом вперед і містять засоби навчання умінням управляти рухами, підвідні вправи та вправу в цілому. Ці роботи складають найбільш тривалий шлях сіті:

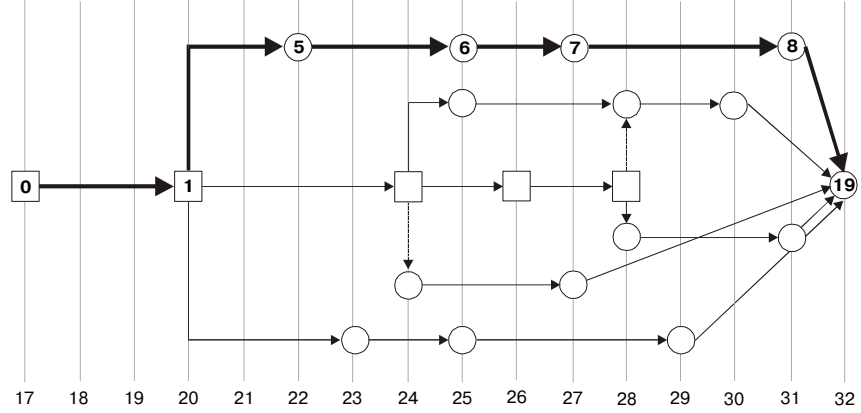

Робота 5-6 триває 4 заняття, робота 6-7 - 2 заняття, робота 7-8 - 4 заняття. У навчанні вправ використовується метод алгоритмічних розпоряджень, який, як відомо, дає гарні результати під час оволодінні вправами шкільної гімнастики (А. М. Шлемін).

Таким чином, сітьовий графік проходження навчального матеріалу будується на основі фізичної готовності і порядку навчання найбільш складному руху і дає можливість уникнути, по можливості, напластування складного матеріалу в одному занятті (див. рис. 22, табл. 1).

На основі сітьового графіка уточнюються завдання навчання (табл. 2), будується тематичний план-графік (табл. 3) та упорядковуються конспекти уроків.

Узагальнена мета занять гімнастикою в школі - розвиток, освіта, виховання школярів. Від поставлених завдань уроку залежить підбір рухових завдань. У різних методичних рекомендаціях стверджується, що в уроці повинно бути три завдання, які тісно зв'язані з узагальненою метою. Це вірно, але кількість завдань залежить від можливості дроблення навчального матеріалу, від логічного зв'язку окремих уроків. Сітьовий графік розподі- 
Таблиця 2

Навчальні завдання для учнів 9-х класів

\begin{tabular}{|c|c|}
\hline $\begin{array}{c}\text { № } \\
\text { уроку }\end{array}$ & Завдання уроку \\
\hline 1 & 2 \\
\hline 17 & $\begin{array}{l}\text { 1. Навчити загальнорозвиваючим вправам у русі } \\
\text { (комплекс 1). } \\
\text { 2. Навчити загальнорозвиваючим вправам у парах } \\
\text { (комплекс 4). } \\
\text { 3. Сприяти розвитку функції рівноваги. } \\
\text { 4. Сприяти розвитку сили м'язів плечового поясу. }\end{array}$ \\
\hline $18-20$ & \begin{tabular}{|l} 
1. Сприяти розвитку функції рівноваги. \\
2. Сприяти розвитку сили м'язів плечового поясу.
\end{tabular} \\
\hline 21 & $\begin{array}{l}\text { 1. Навчити загальнорозвиваючим вправам на місці } \\
\text { (комплекс 3). } \\
\text { Юнаки: } \\
\text { 2. Сприяти розвитку спеціальної рухової підготов- } \\
\text { леності учнів для виконання: } \\
\text { a) підйому переворотом силою; } \\
\text { б) опорного стрибка зігнувши ноги; } \\
\text { в) стійці силою на голові; } \\
\text { г) підйому махом вперед. } \\
\text { 3. Повторити перекиди вперед з різною швидкістю. } \\
\text { Дівчата: } \\
\text { 1. Навчити вису прогнувшись на н.ж., з опорою сто- } \\
\text { пами об в.ж. і переходу в упор на н.ж. } \\
\text { 2. Навчити на р/в брусах зіскоку із сіду на стегні. } \\
\text { 3. Повторити акробатичні вправи. } \\
\text { 4. Повторити стрибок боком. } \\
\end{array}$ \\
\hline 22 & $\begin{array}{l}\text { Юнаки: } \\
\text { 1. Сприяти розвитку спеціальної рухової підготов- } \\
\text { леності учнів для виконання: } \\
\text { a) підйому переворотом силою; } \\
\text { б) опорного стрибка зігнувши ноги; } \\
\text { в) стійці силою на голові. } \\
\text { 2. Навчити підйому махом вперед: друга і третя серії } \\
\text { навчальних завдань. } \\
\text { Дівчата: } \\
\text { 1. Повторити акробатичні вправи. } \\
\text { 2. Повторити опорний стрибок боком. } \\
\text { 3. Навчити вису прогнувшись на н.ж., з опорою сто- } \\
\text { пами об в.ж. і переходу в упор на н.ж. } \\
\end{array}$ \\
\hline \multirow[t]{2}{*}{23} & $\begin{array}{l}\text { Юнаки: } \\
\text { 1. Сприяти розвитку спеціальної рухової підготов- } \\
\text { леності учнів для виконання: } \\
\text { a) стійки силою на голові і руках; } \\
\text { б) підйому переворотом силою. } \\
\end{array}$ \\
\hline & $\begin{array}{l}\text { 2. Навчити підйому махом вперед: четверта серія } \\
\text { навчальних завдань. } \\
\text { 3. Навчити довгому перекиду вперед з трьох кроків: } \\
\text { підвідні вправи. } \\
\text { 4. Навчити стрибку зігнувши ноги через козла: тре- } \\
\text { тя серія навчальних завдань. } \\
\text { Дівчата: } \\
\text { 1. Повторити акробатичні вправи. } \\
\text { 2. Повторити опорний стрибок боком. } \\
\text { 3. Повторити вправи на р/в брусах. }\end{array}$ \\
\hline 24 & $\begin{array}{l}\text { Юнаки: } \\
\text { 1. Навчити підйому переворотом в упор силою. } \\
\text { 2. Навчити підйому махом вперед: четверта серія } \\
\text { навчальних завдань. } \\
\text { 3. Навчити стійці силою на голові і руках: друга } \\
\text { серія навчальних завдань. }\end{array}$ \\
\hline
\end{tabular}

\begin{tabular}{|c|c|}
\hline & $\begin{array}{l}\text { 4. Навчити довгому перекиду вперед з трьох кроків: } \\
\text { підвідні вправи. } \\
\text { 5. Навчити стрибку зігнувши ноги через козла: тре- } \\
\text { тя серія навчальних завдань. } \\
\text { Дівчата: } \\
\text { ті самі завдання, що на } 23 \text { уроці. }\end{array}$ \\
\hline 25 & $\begin{array}{l}\text { Юнаки: } \\
\text { 1. Навчити підйому переворотом в упор силою. } \\
\text { 2. Навчити підйому махом вперед: четверта серія } \\
\text { навчальних завдань. } \\
\text { 3. Навчити стійці силою на голові і руках: підвідні } \\
\text { вправи. } \\
\text { 4. Навчити довгому перекиду вперед } 3 \text { трьох кро- } \\
\text { ків. } \\
\text { 5. Навчити стрибку зігнувши ноги через козла: тре- } \\
\text { тя серія навчальних завдань. } \\
\text { Дівчата: } \\
\text { ті самі завдання, що на } 24 \text { уроці. } \\
\end{array}$ \\
\hline 26 & $\begin{array}{l}\text { Юнаки: } \\
\text { 1. Навчити підйому переворотом в упор силою. } \\
\text { 2. Навчити підйому махом вперед: п’ята серія } \\
\text { навчальних завдань. } \\
\text { 3. Навчити стійці силою на голові і руках: підвідні } \\
\text { вправи. } \\
\text { 4. Навчити довгому перекиду вперед } 3 \text { трьох кро- } \\
\text { ків. } \\
\text { 5. Навчити стрибку зігнувши ноги через козла: тре- } \\
\text { тя серія навчальних завдань. } \\
\text { Дівчата: } \\
\text { ті самі завдання, що на } 25 \text { уроці. }\end{array}$ \\
\hline \multirow[t]{2}{*}{27} & $\begin{array}{l}\text { Юнаки: } \\
\text { 1. Навчити підйому махом вперед: підвідні вправи. } \\
\text { 2. Навчити стійці силою на голові і руках: п’ята серія } \\
\text { навчальних завдань. } \\
\end{array}$ \\
\hline & $\begin{array}{l}\text { 3. Навчити стрибку зігнувши ноги через козла: тре- } \\
\text { тя серія навчальних завдань. } \\
\text { 4. Повторити раніше вивчені вправи. } \\
\text { Дівчата: } \\
\text { ті самі завдання, що на } 26 \text { уроці. } \\
\end{array}$ \\
\hline 28 & $\begin{array}{l}\text { Юнаки: } \\
\text { 1. Навчити стійці силою на голові. } \\
\quad \text { Далі ті самі завдання, що на } 27 \text { уроці. } \\
\text { Дівчата: } \\
\text { ті самі завдання, що на } 27 \text { уроці. } \\
\end{array}$ \\
\hline \multirow[t]{2}{*}{29} & $\begin{array}{l}\text { Юнаки: } \\
\text { 1. Навчити підйому махом вперед. } \\
\text { 2. Навчити стійці силою на голові і руках. } \\
\text { 3. Навчити стрибку зігнувши ноги: п’ята серія } \\
\text { навчальних завдань }\end{array}$ \\
\hline & $\begin{array}{l}\text { 4. Повторити раніше вивчені вправи. } \\
\text { Дівчата: } \\
\text { 1. Повторити раніше вивчені вправи. }\end{array}$ \\
\hline 30 & $\begin{array}{l}\text { Юнаки: } \\
\text { 1. Навчити підйому махом вперед. } \\
\text { 2. Навчити стрибку зігнувши ноги: п’ята серія } \\
\text { навчальних завдань. } \\
\text { 3. Повторити раніше вивчені вправи. } \\
\text { Дівчата: } \\
\text { 1. Повторити раніше вивчені вправи. }\end{array}$ \\
\hline & $\begin{array}{l}\text { 1. Виконати на оцінку контрольні вправи і навчал } \\
\text { ні комбінації. }\end{array}$ \\
\hline
\end{tabular}


лення навчального матеріалу дозволяє поставити коректні завдання до кожного уроку, уникнути надмірного дроблення матеріалу, а також виникнення ситуації негативного переносу рухової навички. Важливе значення у формулюванні завдань уроку має також і підбір методів розвитку рухових здібностей і навчання. Використання комбінованого методу розвитку сили, методу алгоритмічних розпоряджень для навчання вправам дозволяє де- талізувати завдання уроку, зробити їх доступними для реалізації.

На підставі таблиці вихідної інформації (див. табл. 1) сформулюємо завдання і запишемо їх у таблицю 2.

Деталізуємо зміст сітьового графіка проходження навчального матеріалу і визначимо засоби для вирішення завдань уроку. Для цього складемо програми навчання і тематичний план-графік (табл. 3,4$)$.

Таблиця 3

Програма навчання підйому махом уперед з упору на руках на паралельних брусах

\begin{tabular}{|c|c|c|c|}
\hline $\begin{array}{l}\text { № } \\
3 / \Pi\end{array}$ & Інформаційний кадр (що виконуємо?) & Операційний кадр (як виконуємо?) & $\begin{array}{l}\text { Контрольний кадр (коли переходимо } \\
\text { до вивчення нової вправи?) }\end{array}$ \\
\hline \multirow[t]{2}{*}{1} & 2 & 3 & 4 \\
\hline & Перша серія навчальних завдань: & & \\
\hline 1. & $\begin{array}{l}\text { Згинання і розгинання рук в упорі } \\
\text { максимально швидко (5 раз за } 3-4 \mathrm{c}) \text {. }\end{array}$ & $\begin{array}{l}\text { Вправу виконувати максимально } \\
\text { швидко. Зберігати гімнастичний стиль } \\
\text { виконання. }\end{array}$ & $\begin{array}{l}\text { Якщо учень виконує завдання за } 3- \\
4 \text { с, то перейти до наступної вправи. }\end{array}$ \\
\hline \multirow[t]{2}{*}{2.} & $\begin{array}{l}3 \text { упору на руках ривком підйом в } \\
\text { упор. }\end{array}$ & $\begin{array}{l}\text { Вправу виконувати одним рухом, в од- } \\
\text { ному темпі. }\end{array}$ & $\begin{array}{l}\text { Уміти виконати вправу максимально } \\
\text { швидко три рази. }\end{array}$ \\
\hline & Друга серія навчальних завдань: & & \\
\hline 1. & $\begin{array}{l}\text { Фіксувати упор лежачи на руках ноги } \\
\text { нарізно на брусах. }\end{array}$ & $\begin{array}{l}\text { Упродовж } 2 \text { с фіксувати положення } \\
\text { упору лежачи на руках, ноги нарізно на } \\
\text { брусах. Звернути увагу на положення } \\
\text { рук, руки зігнуті в ліктьових суглобах } \\
\text { під кутом } 90^{\circ} \text {. Ліктьові суглоби знахо- } \\
\text { дяться попереду лінії плечового сугло- } \\
\text { ба. }\end{array}$ & $\begin{array}{l}\text { Правильне виконання в серії з трьох } \\
\text { спроб. }\end{array}$ \\
\hline \multirow[t]{2}{*}{2.} & $\begin{array}{l}\text { Упор на руках з додатковим вантажем } \\
3 \text { провисанням в плечах. }\end{array}$ & $\begin{array}{l}\text { Упор на руках виконується з напру- } \\
\text { женням м'язів плечового пояса, прови- } \\
\text { сання здійснюється за рахунок розтя- } \\
\text { гування м'язів плечового поясу. }\end{array}$ & $\begin{array}{l}\text { Правильне виконання в серії з трьох } \\
\text { спроб. }\end{array}$ \\
\hline & Третя серія навчальних завдань: & & \\
\hline 1. & $\begin{array}{l}\text { Розмахування в упорі на руках по мак- } \\
\text { симальній амплітуді. }\end{array}$ & $\begin{array}{l}\text { Звернути увагу на правильне положен- } \\
\text { ня рук і напружене провисання в пле- } \\
\text { чах у момент проходження вертикалі. }\end{array}$ & Уміти виконати 5-6 махів. \\
\hline \multirow[t]{2}{*}{2.} & $\begin{array}{l}\text { Розмахування в упорі на руках з ак- } \\
\text { центованою увагою на хльост ногами } \\
\text { уперед-уверх і активне відштовхуван- } \\
\text { ня плечима від жердин. }\end{array}$ & $\begin{array}{l}\text { Хльост ногами здійснюється уперед- } \\
\text { уверх (до вертлуг жердин), в кінці хль- } \\
\text { осту п’ятки ніг здійснюють рух у зво- } \\
\text { ротньому напрямку і учень відштов- } \\
\text { хується плечима від жердин. }\end{array}$ & $\begin{array}{l}\text { Уміти виконати 3-5 махів з відштов- } \\
\text { хуванням плечима від жердин. }\end{array}$ \\
\hline & Четверта серія навчальних завдань: & & \\
\hline 1. & $\begin{array}{l}\text { Розмахування в упорі на руках по за- } \\
\text { даній амплітуді. }\end{array}$ & $\begin{array}{l}\text { Мах виконується з амплітудою } 30^{\circ}, 60^{\circ} \text {, } \\
90^{\circ} \text {, }\end{array}$ & $\begin{array}{l}\text { Уміти акцентовано виконувати хльо- } \\
\text { стоподібний мах по заданій амплітуді. }\end{array}$ \\
\hline 2. & $\begin{array}{l}\text { Розмахування в упорі на руках з міні- } \\
\text { мальним збільшенням маху уперед. }\end{array}$ & $\begin{array}{l}\text { Перший мах виконується з амплітудою } \\
30^{\circ}, \text { кожний наступний - зі збільшен- } \\
\text { ням амплітуди до кута } 90^{\circ} \text {. }\end{array}$ & $\begin{array}{l}\text { Уміти в одному підході збільшувати } \\
\text { амплітуду маха 5-7 разів. }\end{array}$ \\
\hline \multirow[t]{2}{*}{3.} & $\begin{array}{l}\text { Розмахування в упорі на руках з під- } \\
\text { льотом і мінімальним збільшенням } \\
\text { маху уперед. }\end{array}$ & $\begin{array}{l}\text { Виконання вправи ускладнюється мо- } \\
\text { ментом відштовхування плечима від } \\
\text { жердин. }\end{array}$ & $\begin{array}{l}\text { Уміти в одному підході збільшувати } \\
\text { амплітуду маха 5-7 разів. }\end{array}$ \\
\hline & П’ята серія навчальних завдань & & \\
\hline 1. & $\begin{array}{l}3 \text { упору махом назад зігнути руки, ма- } \\
\text { хом уперед випрямити. }\end{array}$ & $\begin{array}{l}\text { У кінці маху назад зігнути руки, махом } \\
\text { уперед випрямити руки, тіло випрям- } \\
\text { лене, п'ятки - вище жердин. }\end{array}$ & $\begin{array}{l}\text { Правильно виконати вправу в серії } \\
\text { з трьох спроб. }\end{array}$ \\
\hline
\end{tabular}


Продовження табл. 3

\begin{tabular}{|c|c|c|c|}
\hline 1 & 2 & 3 & 4 \\
\hline 2. & $\begin{array}{l}3 \text { упору на передпліччях підйом махом } \\
\text { уперед. }\end{array}$ & $\begin{array}{l}\text { По ходу маху уперед, не доходячи до } \\
\text { вертикалі, хльостоподібним махом } \\
\text { прогнутися і пружно провисаючи в } \\
\text { плечових суглобах, енергійно напра- } \\
\text { вити ноги уперед-уверх, згинаючись у } \\
\text { кульшових суглобах (до } 135^{\circ} \text { ). Трохи } \\
\text { раніше, чим ноги досягнуть рівня жер- } \\
\text { дин, різко розігнутися, пригальмувати } \\
\text { рух ніг, виконати енергійний ривок } \\
\text { грудьми і відштовхнутися передпліч- } \\
\text { чями від жердин. Натискуючи руками } \\
\text { на жердини, перейти в упор, продов- } \\
\text { жуючи мах уперед. }\end{array}$ & $\begin{array}{l}\text { Правильно виконати вправу в серії } \\
\text { з трьох спроб. }\end{array}$ \\
\hline \multirow[t]{2}{*}{3.} & $\begin{array}{l}\text { На похилих брусах підйом махом упе- } \\
\text { ред в сід ноги нарізно. }\end{array}$ & $\begin{array}{l}\text { Те саме з відштовхуванням плечима від } \\
\text { жердин, перехід у сід здійснюється піс- } \\
\text { ля підйому в упор. }\end{array}$ & $\begin{array}{l}\text { Правильно виконати вправу в серії } \\
\text { з трьох спроб. }\end{array}$ \\
\hline & Шоста серія навчальних завдань & & \\
\hline 1. & Підйом махом уперед з допомогою. & $\begin{array}{l}\text { У момент енергійного ривка грудьми } \\
\text { і відштовхування плечима від жердин } \\
\text { надати допомогу (підштовхування). }\end{array}$ & $\begin{array}{l}\text { Правильно виконати вправу в серії } \\
\text { з трьох спроб. }\end{array}$ \\
\hline 2. & Підйом махом уперед самостійно. & $\begin{array}{l}\text { Підйом махом уперед виконується від- } \\
\text { повідно до описаної техніки. }\end{array}$ & $\begin{array}{l}\text { Правильно виконати вправу в серії } \\
\text { з трьох спроб. }\end{array}$ \\
\hline 3. & $\begin{array}{l}\text { Підйом махом уперед - зіскок махом } \\
\text { назад. }\end{array}$ & $\begin{array}{l}\text { Звернути увагу на техніку виконання } \\
\text { маху назад після підйому в упор. }\end{array}$ & $\begin{array}{l}\text { Правильно виконати вправу в серії } \\
\text { з трьох спроб. }\end{array}$ \\
\hline
\end{tabular}

У тематичний план-графік (див. табл. 4) внесемо всі вправи, які вивчаються в дев'ятому класі. Для кожної вправи складемо навчальну програму типу алгоритмічних розпоряджень. Під кожною вправою запишемо серії навчальних завдань. Вправи розташуємо в порядку складності. На основі сітьвого графіка визначимо порядок і строки виконання серій навчальних завдань. Вправи серій навчальних завдань підбираються так, щоб учні змогли їх засвоїти на одному уроці. Напроти вправи, в графі номера уроку позначаємо навчання («н»), якщо вправу виконуємо перший раз, або повторення («п»), якщо вправа виконувалася на попередньому уроці. Для розвитку сили окремих груп м'язів використаємо засоби, які рекомендуються програмою, а також перші серії навчальних завдань вправ, які вивчаються.

Міцність рухової навички в гімнастиці визначається можливістю виконання вивченої вправи у сполученні, у комбінації. У тематичному плані передбачимо, після оволодіння програмним матеріалом, виконання комбінацій на кожному снаряді. Останні два уроки присвячуємо контролю за оволодінням програмним матеріалом. Для цього заплануємо виконання комбінацій і навчальних нормативів, і відповідно в графах номера уроків поставимо позначку контролю («К»).

Ефективність технологічного підходу у навчанні гімнастичним вправам наведеного вище описана в роботах $[13,14]$.

\section{Висновки}

1. Педагогічна технологія виступає як система, до якої входять учасники педагогічного процесу та система теорій, ідей, засобів і методів організації навчальної діяльності для ефективного забезпечення розв'язання проблем, що охоплюють всі аспекти засвоєння знань і практичних умінь.

2. У рамках навчання вирішуються завдання розвитку рухових здібностей, підвищення рівня спеціально-рухової підготовленості для засвоєння конкретних вправ. Практично це реалізується в послідовному розміщенні навчальних завдань на певному часовому відрізку. Рішення завдань і підбір серій навчальних вправ здійснюється в такій послідовності:

- розвиток рухових здібностей, які забезпечують ефективне виконання вправи, яку вивчають;

- навчання вихідним і кінцевим положенням вправи;

- навчання діям, без яких неможливо виконати вправу, що вивчається;

- навчання вмінням управляти рухами;

- навчання підвідним вправам;

- навчання вправі в сполученні або в комбінації.

3. Сітьовий графік проходження навчального матеріалу будується на основі фізичної готовності 
Тематичний план-графік проходження навчального матеріалу з гімнастики для учнів 9-х класів

\begin{tabular}{|c|c|c|c|c|c|c|c|c|c|c|c|c|c|c|c|c|c|}
\hline № & Зміст & 17 & 18 & 19 & 20 & 21 & 22 & 23 & 24 & 25 & 26 & 27 & 28 & 29 & 30 & 31 & 32 \\
\hline 1 & Основи знань & + & + & + & + & + & + & + & + & + & + & + & + & + & + & + & + \\
\hline \multirow[t]{4}{*}{2} & Стройові вправи: & & & & & & & & & & & & & & & & \\
\hline & а) перестроювання в русі; & п & п & $\Pi$ & $\Pi$ & п & п & п & $\Pi$ & $\Pi$ & $\Pi$ & п & $\Pi$ & $\Pi$ & $\Pi$ & $\Pi$ & $\Pi$ \\
\hline & б) рух до точок залу; & п & п & $\Pi$ & $\Pi$ & п & п & п & $\Pi$ & $\Pi$ & п & $\Pi$ & $\Pi$ & $\Pi$ & $\Pi$ & $\Pi$ & $\Pi$ \\
\hline & в) рухи протиходом, «змійкою» & п & п & $\Pi$ & $\Pi$ & п & п & п & $\Pi$ & $\Pi$ & п & п & $\Pi$ & $\Pi$ & $\Pi$ & $\Pi$ & $\Pi$ \\
\hline \multirow[t]{4}{*}{3} & Загальнорозвиваючі вправи: & & & & & & & & & & & & & & & & \\
\hline & a) y pyci $(№ 1,2)$; & $\mathrm{H}$ & $\Pi$ & $\Pi$ & $\Pi$ & $\Pi$ & $\Pi$ & $\Pi$ & $\Pi$ & $\mathrm{H}$ & $\Pi$ & $\Pi$ & $\Pi$ & $\Pi$ & $\Pi$ & $\Pi$ & $\Pi$ \\
\hline & б) на місці (№ 3); & & & & & $\mathrm{H}$ & п & п & $\Pi$ & $\Pi$ & $\Pi$ & п & $\Pi$ & $\Pi$ & $\Pi$ & $\Pi$ & $\Pi$ \\
\hline & в) у парах (№ 4) & $\mathrm{H}$ & п & $\Pi$ & $\Pi$ & & & & & & & & & & & & \\
\hline \multirow[t]{4}{*}{4} & Виси і упори: & & & & & & & & & & & & & & & & \\
\hline & Юнаки & & & & & & & & & & & & & & & & \\
\hline & Перекладина: & & & & & & & & & & & & & & & & \\
\hline & із вису підйом переворотом в упор силою & & & & & + & + & + & + & + & + & + & & & & & \\
\hline- & із вису на зігнутих руках вис прогнувшись; & & & & & $\mathrm{H}$ & п & $\Pi$ & $\Pi$ & $\Pi$ & п & & & & & & \\
\hline- & із положення лежачи на перекладині упор; & & & & & $\mathrm{H}$ & п & $\Pi$ & $\Pi$ & $\Pi$ & п & & & & & & \\
\hline- & підйом переворотом в упор з допомогою; & & & & & & $\mathrm{H}$ & $\mathrm{H}$ & $\mathrm{H}$ & & & & & & & & \\
\hline- & підйом переворотом в упор самостійно. & & & & & & & & & $\mathrm{H}$ & $\mathrm{H}$ & K & & & & & \\
\hline \multirow[t]{3}{*}{-} & навчальна комбінація & & & & & & & 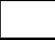 & & & . & & $\Pi$ & $\Pi$ & $\Pi$ & К & к \\
\hline & Бруси: & & & & & & & & & & & & 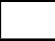 & & 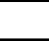 & & \\
\hline & з упору на руках підйом махом вперед & & & & & + & + & + & + & + & + & + & + & + & + & + & \\
\hline- & розмахування в упорі; & & & & & п & $\Pi$ & п & $\Pi$ & $\Pi$ & п & $\Pi$ & $\Pi$ & $\Pi$ & $\Pi$ & $\Pi$ & \\
\hline- & упор на руках з провисанням; & & & & & $\Pi$ & $\Pi$ & & & & & & & & & & \\
\hline- & розмахування в упорі на руках; & & & & & п & п & $\Pi$ & $\Pi$ & $\Pi$ & п & п & $\Pi$ & $\Pi$ & $\Pi$ & $\Pi$ & \\
\hline- & розмахування в упорі на руках по заданій амплітуді; & & & & & & $\mathrm{H}$ & $\Pi$ & & & & & & & & & \\
\hline- & $\begin{array}{l}\text { розмахування в упорі на руках з мінімальним збільшен- } \\
\text { ням маху вперед; }\end{array}$ & & & & & & & $\mathrm{H}$ & $\Pi$ & $\Pi$ & & & & & & & \\
\hline- & $\begin{array}{l}\text { розмахування в упорі на руках з підльотом і мінімаль- } \\
\text { ним збільшенням маху вперед; }\end{array}$ & & & & & & & & $\mathrm{H}$ & $\mathrm{H}$ & п & $\Pi$ & $\Pi$ & $\Pi$ & $\Pi$ & & \\
\hline- & з упору на зігнутих руках підйом махом вперед; & & & & & & & & & & $\mathrm{H}$ & & & & & & \\
\hline- & з упору на передпліччях підйом махом вперед; & & & & & & & & & & $\mathrm{H}$ & $\Pi$ & $\Pi$ & & & & \\
\hline- & $\begin{array}{l}\text { на похилих брусах підйом махом вперед у сід ноги наріз- } \\
\text { но; }\end{array}$ & & & & & & & & & & & $\mathrm{H}$ & п & & & & \\
\hline- & підйом махом вперед з допомогою; & & & & & & & & & & & & $\mathrm{H}$ & $\Pi$ & & & \\
\hline- & підйом махом вперед самостійно; & & & & & & & & & & & & & $\mathrm{H}$ & $\mathrm{H}$ & K & \\
\hline \multirow[t]{4}{*}{-} & підйом махом вперед і зіскок махом назад. & & & & & & & & & & & & & & $\mathrm{H}$ & $\mathrm{H}$ & \\
\hline & Навчальна комбінація & & & & & & & & & & & & & $\Pi$ & $\Pi$ & K & K \\
\hline & Дівчата & & & & & & & & & & & & & & & & \\
\hline & Різновисокі бруси: & & & & & & & & & & & & & & & & \\
\hline- & $\begin{array}{l}\text { вис прогнувшись на н.ж., упираючись стопами об в.ж., } \\
\text { перехід в упор на н.ж.; }\end{array}$ & & & & & $\mathrm{H}$ & $\mathrm{H}$ & $\mathrm{H}$ & $\Pi$ & $\Pi$ & п & $\Pi$ & $\Pi$ & $\Pi$ & $\Pi$ & $\Pi$ & \\
\hline- & $\begin{array}{l}\text { махом одною і поштовхом другою підйом переворотом } \\
\text { в упор на н.ж.; }\end{array}$ & & & & & $\Pi$ & $\Pi$ & $\Pi$ & $\Pi$ & $\Pi$ & п & $\Pi$ & $\Pi$ & $\Pi$ & $\Pi$ & к & \\
\hline \multirow[t]{2}{*}{-} & зіскок з сіду на стегні. & & & & & $\mathrm{H}$ & $\Pi$ & $\Pi$ & $\Pi$ & $\Pi$ & п & $\Pi$ & $\Pi$ & $\Pi$ & $\Pi$ & K & \\
\hline & Навчальна комбінація. & & & & & & & & & & & п & $\Pi$ & п & п & к & к \\
\hline 5 & Вправи в рівновазі на підлозі: & + & + & + & + & & & & & & & & & & & & \\
\hline- & підскоки на одній нозі; & + & + & + & + & & & & & & & & & & & & \\
\hline- & напівприсід; & + & + & + & + & & & & & & & & & & & & \\
\hline- & сід кутом; & + & + & + & + & & & & & & & & & & & & \\
\hline- & поворот в присіді; & + & + & + & + & & & & & & & & & & & & \\
\hline \multirow[t]{2}{*}{-} & зіскок з напівприсіда. & + & + & + & + & & & & & & & & & & & & \\
\hline & На лаві: & & & & & & & & & & & & & & & & \\
\hline- & підскоки на одній нозі; & & + & + & + & & & & & & & & & & & & \\
\hline- & напівприсід; & & + & + & + & & & & & & & & & & & & \\
\hline- & сід кутом; & & + & + & + & & & & & & & & & & & & \\
\hline- & поворот в присіді; & & + & + & + & & & & & & & & & & & & \\
\hline- & зіскок з напівприсіда. & & + & + & + & & & & & & & & & & & & \\
\hline
\end{tabular}


Худолій О.М. Технологія навчання гімнастичним вправам

\begin{tabular}{|c|c|c|c|c|c|c|c|c|c|c|c|c|c|c|c|c|c|}
\hline № & Номери уроків & 17 & 18 & 19 & 20 & 21 & 22 & 23 & 24 & 25 & 26 & 27 & 28 & 29 & 30 & 31 & 32 \\
\hline & Вирави на колоді: & & & & & & & & & & & & & & & & \\
\hline- & підскоки на одній нозі; & & & + & + & & & & & & & & & & & & \\
\hline- & напівприсід; & & & + & + & & & & & & & & & & & & \\
\hline- & сід кутом; & & & + & + & & & & & & & & & & & & \\
\hline- & поворот в присіді; & & & + & + & & & & & & & & & & & & \\
\hline \multirow[t]{2}{*}{-} & зіскок з напівприсіда. & & & + & + & & & & & & & & & & & & \\
\hline & Навчальна комбінація. & & & & & & & & $\Pi$ & п & $\Pi$ & $\Pi$ & $\Pi$ & $\Pi$ & $\Pi$ & $\Pi$ & $\Pi$ \\
\hline \multirow[t]{3}{*}{6} & Акробатичні вправи: & & & & & & & & & & & & & & & & \\
\hline & Юнаки & & & & & & & & & & & & & & & & \\
\hline & стійка силою на голові і руках & & & & & + & + & + & + & + & + & + & & & & & \\
\hline- & $\begin{array}{l}3 \text { упору стоячи зігнувшись спиною до гімнастичної } \\
\text { стінки перехід у вис прогнувшись; }\end{array}$ & & & & & п & $\Pi$ & $\Pi$ & $\Pi$ & & & & & & & & \\
\hline- & $\begin{array}{l}\text { з упору присівши обпертися головою об мат на розмітку } \\
\text { і рівномірно передати вагу тіла на руки і голову }\end{array}$ & & & & & & & & $\mathrm{H}$ & $\pi$ & $\Pi$ & & & & & & \\
\hline- & $\begin{array}{l}\text { те саме, але, піднімаючи ноги від підлоги і утримуючи їх } \\
\text { зігнутими, випрямити спину; }\end{array}$ & & & & & & & & & $\mathrm{H}$ & $\mathrm{H}$ & $\Pi$ & & & & & \\
\hline- & $\begin{array}{l}\text { стійка на голові і руках самостійно з опорою спиною і но- } \\
\text { гами об стінку; }\end{array}$ & & & & & & & & & & H & $\mathrm{H}$ & $\Pi$ & & & & \\
\hline \multirow[t]{2}{*}{-} & стійка на голові і руках. & & & & & & & & & & & & $\mathrm{H}$ & $\mathrm{H}$ & к & & \\
\hline & Довгий перекид з трьох кроків & & & & & & & & & & & & & & & & \\
\hline- & перекид вперед з різною швидкістю; & & & & & п & $\Pi$ & $\Pi$ & $\Pi$ & & & & & & & & \\
\hline- & перекид з розбігу на горку матів; & & & & & & & $\mathrm{H}$ & $\mathrm{H}$ & п & $\Pi$ & & & & & & \\
\hline \multirow[t]{3}{*}{-} & перекид вперед через мотузку. & & & & & & & & & $\mathrm{H}$ & $\mathrm{H}$ & $\mathrm{H}$ & $\mathrm{H}$ & K & & & \\
\hline & Навчальна комбінація & & & & & & & & & & - & & $\Pi$ & $\bar{\Pi}$ & п & K & К \\
\hline & Дівчата & & & & & & & & & & & & & & & & \\
\hline- & рівновага на одній нозі, випад уперед; & & & & & п & $\Pi$ & $\Pi$ & $\Pi$ & п & $\Pi$ & п & $\Pi$ & $\Pi$ & & & \\
\hline- & перекиди уперед, назад; & & & & & п & $\Pi$ & $\Pi$ & $\Pi$ & п & $\Pi$ & п & $\Pi$ & $\Pi$ & & & \\
\hline- & «міст» і поворот в упор стоячи на колінах; & & & & & п & $\Pi$ & $\Pi$ & $\Pi$ & п & п & п & $\Pi$ & п & & & \\
\hline \multirow[t]{2}{*}{-} & перекид назад в напівшпагат. & & & & & п & $\Pi$ & $\Pi$ & $\Pi$ & $\Pi$ & $\Pi$ & п & $\Pi$ & $\Pi$ & & & \\
\hline & Навчальна комбінація & & & & & & & & & & - & & $\Pi$ & п & п & К & К \\
\hline \multirow[t]{3}{*}{7} & Опорний стрибок & & & & & & & & & & & & & & & & \\
\hline & Юнаки & & & & & & & & & & & & & & & & \\
\hline & стрибок зігнувщи ноги (козел в довжину, $h=115$ см) & & & & & + & + & + & + & + & + & + & + & + & + & + & \\
\hline- & $\begin{array}{l}\text { з упору лежачи поштовхом ніг упор присівши і в темп упор } \\
\text { лежачи; }\end{array}$ & & & & & $\mathrm{H}$ & $\Pi$ & $\Pi$ & $\Pi$ & п & п & п & п & & & & \\
\hline- & $\begin{array}{l}\text { з упору лежачи поштовхом ніг упор присівши і в темп } \\
\text { встати, руки вверх-назовні; }\end{array}$ & & & & & & H & $\Pi$ & $\Pi$ & п & $\Pi$ & $\Pi$ & $\Pi$ & & & & \\
\hline- & $\begin{array}{l}\text { з упору лежачи одночасним поштовхом руками і ногами } \\
\text { присід, руки вперед; }\end{array}$ & & & & & & & H & $\Pi$ & п & $\Pi$ & п & $\Pi$ & & & & \\
\hline- & $\begin{array}{l}\text { вскок в упор присівши на козла в ширину і в темпі зіскок } \\
\text { уперед прогнувшись }(\mathrm{h}=1 \text { м); } 3 \text { розбігу } 3 \text { м вскок в упор } \\
\text { присівши на козла і в темпі зіскок зігнувши ноги; }\end{array}$ & & & & & & & & & & & & п п & п п & & & \\
\hline- & $\begin{array}{l}\text { з упору присівши, руки на лаві, стрибок зігнувши ноги } \\
\text { через гімнастичну лаву; }\end{array}$ & & & & & & & & & & & & $\Pi$ & п & п & & \\
\hline- & $\begin{array}{l}\text { 3 5-7 кроків розбігу стрибок зігнувши ноги через козла } \\
\text { в ширину; }\end{array}$ & & & & & & & & & & & & $\Pi$ & п & п & & \\
\hline \multirow[t]{3}{*}{-} & $\begin{array}{l}\text { з розбігу стрибок зігнувши ноги через козла в довжину } \\
(\mathrm{h}=115 \mathrm{~cm})\end{array}$ & & & & & & & & & & & & H & $\overline{\mathrm{H}}$ & н & $\overline{\mathrm{H}}$ & к \\
\hline & Дівчата & & & & & & & & & & & & & & & & \\
\hline & стрибок боком (кінь в ширину, $h=110 \mathrm{~cm}$ ) & & & & & & & & & & & & & & & & \\
\hline- & настрибнути на коня в упор боком вправо (вліво); & & & & & $\Pi$ & $\Pi$ & & & & & & & & & & \\
\hline- & стрибок боком, упираючись одною ногою об коня; & & & & & $\Pi$ & $\Pi$ & & & & & & & & & & \\
\hline- & стрибок боком з розбігу. & & & & & $\Pi$ & $\Pi$ & $\Pi$ & $\Pi$ & п & $\Pi$ & $\Pi$ & $\Pi$ & $\Pi$ & $\Pi$ & $\Pi$ & K \\
\hline 8 & Вправи для розвитку рухових здібностей: & & & & & & & & & & & & & & & & \\
\hline- & з упору на руках ривком упор; & + & + & + & + & & & & & & & & & & & & \\
\hline- & згинання-розгинання рук в упорі на швидкість; & + & + & + & + & & & & & & & & & & & & \\
\hline- & згинання-розгинання рук в упорі; & + & + & + & + & & & & & & & & & & & & \\
\hline- & згинання-розгинання рук у висі. & + & + & + & + & & & & & & & & & & & & \\
\hline 9 & Контрольні вправи & & & & & & & & & & & & & & & К & K \\
\hline
\end{tabular}


і порядку навчання найбільш складному руху і дає можливість уникнути, по можливості, напластування складного матеріалу в одному занятті.

4. Технологія навчання гімнастичним вправам включає в себе засоби, методи, чітке проектування і відтворення педагогічних дій, які гарантують успіх.

5. Перспективним напрямком досліджень $\epsilon$ розробка методології створення технологічних процесів у навчанні фізичним вправам.

\section{Список літератури}

1. Берг А. И., Тихонов И. И. Проблемы программированного обучения // Программированное обучение. - Л.: Знание, 1968. - С. 3-22.

2. Беспалько В. П. Программированное обучение: дидактические основы. - М.: Высшая школа, 1970. $-300 \mathrm{c}$.

3. Боген М. М. Обучение двигательным действиям. - М.: Физкультура и спорт, 1985. - 192 с.

4. Боген М. М. Задачи обучения двигательным действиям // Теория и практика физической культуры. - 1981. - № 3. - С. 24-27.

5. Боген М. М. Спортивная техника как предмет обучения // Теория и практика физической культуры. - 1981. - № 7. - C. 28-29.
6. Верхошанский Ю. В. Программирование и организация тренировочного процесса. - М.: Физкультура и спорт, 1985. - 176 с.

7. Мазниченко В. Д. Методологические предпосылки к пониманию сущности и механизмов двигательных навыков // Теория и практика физ. культуры. - 1984. — № 7. - С. 49-51.

8. Менхин А. В., Шлемин А. М. Методика обучения гимнастическим упражнениям // Гимнастика: Учебник для институтов физ. культуры. - М.: Физкультура и спорт, 1979. - Гл. 4. - С. 45-47.

9. Пєхота О.М. Освітні технології: Навч.-метод. посіб. / О.М. Пєхота, А.З. Кіктенко, О.М. Любарська та ін. - K.: A.C.K., 2001. - 256 c.

10. Прокопенко І.Ф. Педагогічні технології: Навч. посібник / І.Ф. Прокопенко, В.І. Євдокимов. - Харків: Колегіум, 2005. - 224 c.

11. Селевко Г.К. Педагогические технологии на основе активизации, интенсификации и эффективного управления УВП. - М.: НИИ школьных технологий, 2005. $-288 \mathrm{c}$.

12. Фарфель В. С. Управление движениями в спорте. - М.: Физкультура и спорт, 1975. - 226 с.

13. Худолій O.M. Теоретичні основи планування навчальної роботи з фізичної культури в школі / O.M. Худолій, А.В. Забора // Теорія і практика фізичного виховання. - Харків: ОВС, 2001. - № 1. - С. 3-12.

14. Худолій О.М. Методика планування навчальної роботи з гімнастики в школі // Теорія та методика фізичного виховання. - Харків: ОВС, 2008. - № 9. - C. $19-35$.

Надійшла до редакиії 20.07.2009

Худолей О.Н. Технология обучения гимнастическим упражнениям.

В статье рассматриваются общие подходы к методам обучения, которые используются в физическом воспитание. Данна характеристика: методам обучения, технологизации процесса обучения гимнастическим упражнениям.

Ключевые слова: метод, метод обучения, метод алгоритмических распоряжений, сетевое планирование.

Khudolii O.N. Technology of teaching to the physical drills.

In article general approaches are considered to the methods of teaching, which are used in physical education. Description is given: to the methods of teaching, technologies are considered of process of teaching to the physical drills.

Keywords: method, method of teaching, method of algorithmic orders, network planning. 